\title{
New records of the tylosaurine mosasaur Hainosaurus from the Campanian-Maastrichtian (Late Cretaceous) of central Poland
}

\author{
J.W.M. Jagt ${ }^{1,}{ }^{*}$, J. Lindgren ${ }^{2}$, M. Machalski ${ }^{3} \&$ A. Radwański ${ }^{4}$
}

1 Natuurhistorisch Museum Maastricht, de Bosquetplein 6, NL-6211 KJ Maastricht, the Netherlands.

2 GeoBioSphere Centre, Department of Geology, Lund University, Sölvegatan 12, SE-223 62 Lund, Sweden.

3 Instytut Paleobiologii PAN, ul. Twarda 51/55, PL 00-818 Warszawa, Poland.

4 Instytut Geologii Podstawowej, Wydział Geologii UW, Al. Żwirki i Wigury 93, PL 02-089 Warszawa, Poland.

* Corresponding author. Email: john.jagt@maastricht.nl

Manuscript received: October 2004; accepted: February 2005

\begin{abstract}
Two isolated mosasaur teeth, one from the upper Campanian of Piotrawin, the other from the upper Maastrichtian at Nasilów (Wisla River valley, central Poland), recently described as Plioplatecarpinae sp. A and Plioplatecarpinae sp. B, respectively, are reassigned to the tylosaurine genus Hainosaurus Dollo, 1885. The present record thus adds to the list of Hainosaurus species known to date from elsewhere in Europe (Sweden, Belgium and England).
\end{abstract}

Keywords: Mosasauridae, Tylosaurinae, Hainosaurus, Campanian, Maastrichtian, Poland

\section{Introduction}

In the Campanian-Maastrichtian (Late Cretaceous) sequence of central Poland (Wisla River valley), remains of mosasaurid reptiles are comparatively rare and generally comprise isolated teeth and tooth crowns only. Yet, a fairly diverse assemblage (five taxa, based on tooth morphology) has recently been recorded (Machalski et al., 2003). Those authors discussed and illustrated two isolated teeth, under the names of Plioplatecarpinae sp. A and Plioplatecarpinae sp. B; this record is here revised, and both teeth are reassigned to the tylosaurine genus Hainosaurus Dollo, 1885.

\section{Description}

A fragmentary bicarinate tooth crown (IGPUW AR-5) in the A. Radwański Collection (Instytut Geologii Podstawowej, Uniwersytet Warszawski) is from an opoka facies of late Campanian (Nostoceras hyatti $=N$. pozaryskii Zone) age, exposed at Piotrawin. This was referred to as Plioplatecarpinae sp. A by Machalski et al. (2003, p. 405, fig. 9B). As preserved, IGPUW AR-5 measures $38.0 \mathrm{~mm}$ in height, and $20.2 \mathrm{~mm}$ in basal width. The cross section is elliptical, with lingual and buccal surfaces of subequal convexity. The anterior carina is sharp and well developed, the posterior one not preserved; no serrations are seen, but this may be a matter of preservation. There is a slight posterior recurvature, and the buccal surface shows at least seven facets of unequal width (Fig. 1), the lingual one 9-10; these do not reach mid-height. On both surfaces, very faint striae are visible, confined to the proximal portion of the crown, which is smooth otherwise. The upper portion of the tooth crown is broken; in anterior view, a slight lingual recurvature may be seen.

The second, bicarinate tooth crown (MKD.MP-18; Fig. 2), housed in the collections of Muzeum Nadwiślańskie (Kazimierz Dolny), is from the upper Maastrichtian (Belemnella (Neobelemnella) kazimiroviensis Zone) at Nasilów. Machalski et al. (2003, p. 405, fig. 9A) referred to this as Plioplatecarpinae 


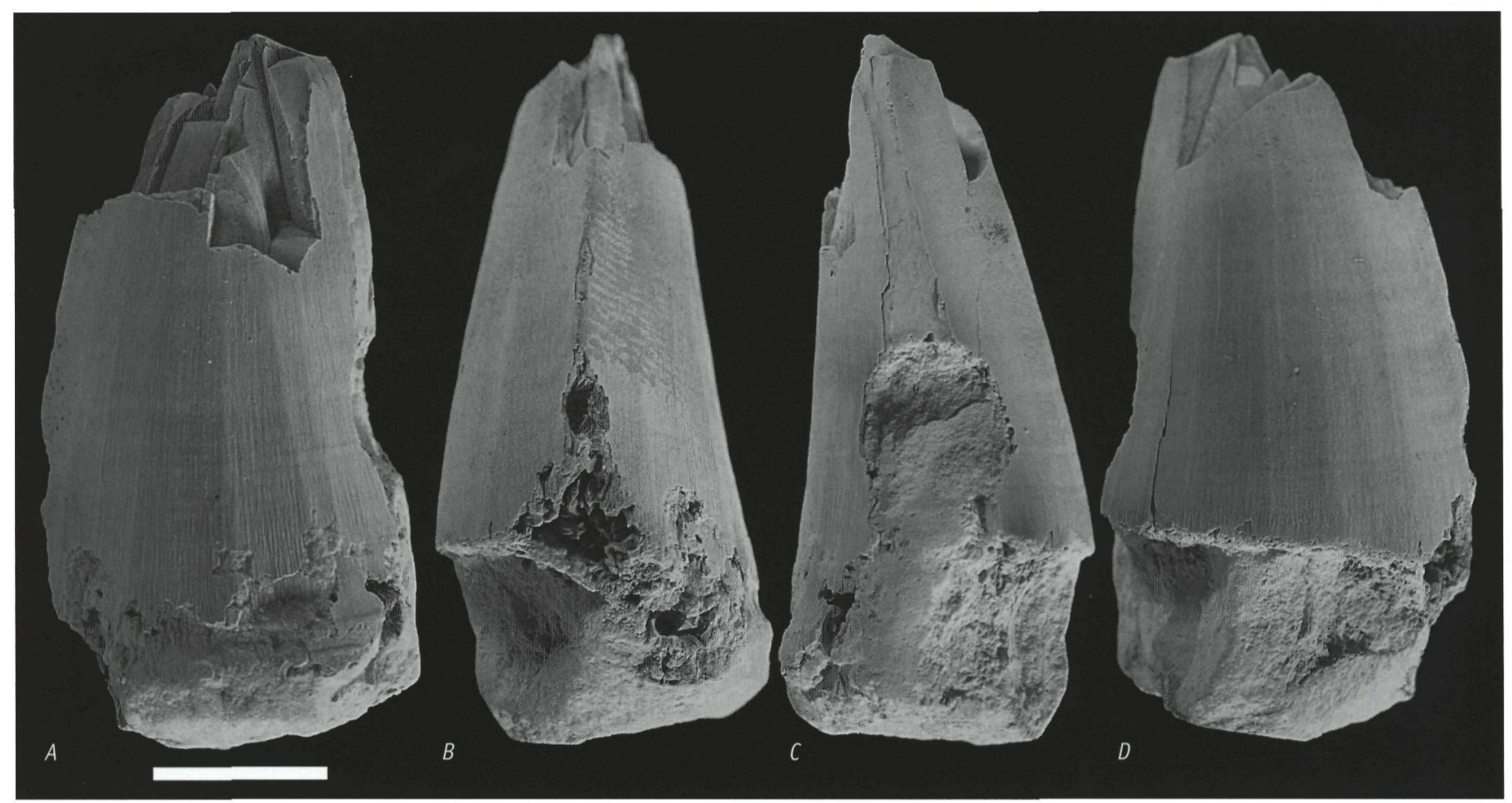

Fig. 1. Hainosaurus sp. 1 (IGPUW AR-5), upper Upper Campanian (Nostoceras pozaryskii = N. hyatti Zone), Piotrawin, in A - lingual; $B-$ mesial (posterior); C-mesial (anterior); and D - buccal views, respectively. Specimen whitened prior to photography; scale bar equals $5 \mathrm{~mm}$.

sp. B. As preserved, MKD.MP-18 measures $24 \mathrm{~mm}$ in height, and $8.6 \mathrm{~mm}$ in width at the base. In cross section, it is elliptical, with subequal lingual and buccal surfaces. Both carinae are well developed and serrations are preserved in patches only. There is a slight posterior and lingual recurvature; the buccal surface shows at least seven facets of comparable width, the lingual one 11-12, not reaching midheight. Very faint striae occur close to the base, on both surfaces, the crown being smooth otherwise.

\section{Discussion}

Examination of dental morphology is an important, yet underutilized tool in mosasaur taxonomy. With few exceptions, dental characters have received only scant attention in systematic studies of mosasaurs, and in general, detailed descriptions of teeth accompanied by high-quality illustrations, are exceedingly rare in the literature. In the majority of cases, teeth are only described in vague, rather uninformative terms.

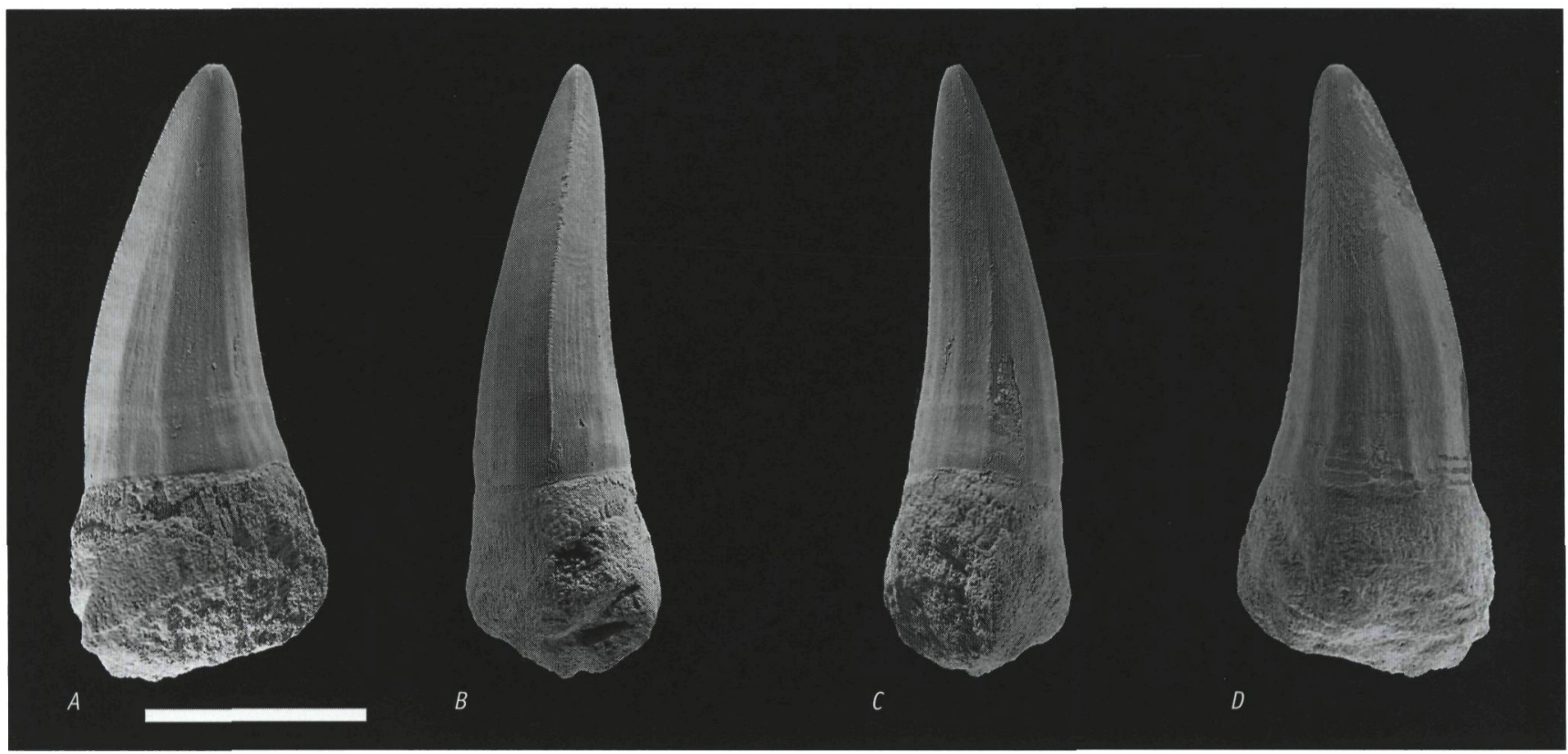

Fig. 2. Hainosaurus sp. 2 (MKD.MP-18), upper Maastrichtian (Belemnella (Neobelemnella) kazimiroviensis Zone), Nasiłów, in $A-l i n g u a l ; ~ B-$ mesial (posterior); $C$-mesial (anterior); and D-buccal views, respectively. Specimen whitened prior to photography; scale bar equals $5 \mathrm{~mm}$. 
This has seriously hampered comparisons between the various taxa, and, consequently, dental morphology has been considered to be unreliable in most taxonomic studies of mosasaurs.

However, from personal experience and first-hand examination of reasonably complete mosasaur skeletons, with the emphasis on dental characters, we know that differences in skeletal anatomy are invariably mirrored by differences in tooth morphology. Accordingly, isolated mosasaur teeth may be identified with confidence, at least to the generic level, in the majority of cases. Naturally, differences relating to ontogeny and jaw position, as well as a certain range of variation within a certain taxon must be considered when assessing the potential of isolated teeth. For instance, the marginal dentition is well differentiated in the genera Clidastes Cope, 1868, Dollosaurus Yakovlev, 1901 and in the durophagous mosasaurs Carinodens Thurmond, 1969 and Globidens Gilmore, 1912, whereas teeth are more uniform in Platecarpus Cope, 1869, Ectenosaurus Russell, 1967 and Plioplatecarpus Dollo, 1882. Obviously, these differences reflect varying feeding strategies and adaptations, where, e.g. the slender and pointed teeth of Platecarpus, Plioplatecarpus and Ectenosaurus probably had a piercing function, specially adapted to penetration between thin, but closely spaced, ribs (see Massare, 1987).

Tylosaurine mosasaurs have generally been considered to possess closely similar dental apparatuses, comprised of moderately differentiated and very robust tooth crowns. However, as demonstrated by Lindgren \& Siverson (2002), this assertion is erroneous; rather, marginal teeth of at least the two Northern Hemisphere genera Tylosaurus Marsh, 1872 and Hainosaurus, can be readily separated from one another by dental characters alone. This discovery has led to the conclusion that there are no verified records of Hainosaurus from North America, whereas Tylosaurus is present on both continents (Lindgren \& Siverson, 2002; Everhart, 2005; Lindgren, 2004, in press).

Machalski et al. (2003) were of the opinion that the combination of facetting with proximal striae and a slight lingual recurvature of IGPUW AR-5 and MKD.MP-18 was reminiscent of teeth assigned to the plioplatecarpine genera Platecarpus and Plioplatecarpus. However, comparison of these specimens with tooth crowns from the upper lower Campanian (Belemnellocamax mammillatus Zone) of southern Sweden described by Lindgren (in press) suggests they are better interpreted as species of Hainosaurus. In particular, the flattened profile and the fact that carinae are serrated, a character unknown in plioplatecarpine mosasaurs, favour such an assignment. Swedish material is slightly smaller, has markedly facetted, enamelled surfaces ( 8 - 10 facets buccally, 11 - 12 lingually) and shows minute serrations on anterior and posterior carinae. More material from central Poland is needed to determine the relationship between these two taxa (of late Campanian and late Maastrichtian age, respectively) and between the Polish specimens and species of Hainosaurus from elsewhere in Europe.
So far, Hainosaurus seems to be an exclusively European genus (but see also Bell et al., 1999), with records from the uppermost lower Campanian of the Kristianstad Basin and the mid-Campanian of the Vomb Trough (both southern Sweden; Lindgren, 2004, in press), the lower Campanian of NE Belgium (Platecarpus sp. sensu Kuypers et al., 1998, p. 37, pl. 7, figs 1-3), the upper Campanian and upper Maastrichtian of central Poland (this paper), the upper Campanian of Norfolk, England ('Leiodon [sic] anceps 0wen, 1845', see Lingham-Soliar, 1993, figs $5 b-d, 6 b, c)$, and the lower Maastrichtian of southern Belgium (Mons Basin, type area of Hainosaurus bernardi) (Dollo, 1885; Lingham-Soliar, 1992).

\section{Acknowledgements}

We thank W. Kowalczyk (Muzeum Nadwiślańskie, Kazimierz Dolny) for loan of specimen MKD.MP-18, and M. Dziewiński (Instytut Paleobiologii, Polska Akademia Nauk, Warszawa) for preparation of photographs.

\section{References}

Bell, G.L. Jr, Caldwell, M.W., Holmes, R., Wiffen, J. \& McKee, J., 1999. Sea monsters of the South Pacific: on the Late Cretaceous mosasaurs of New Zealand. Journal of Vertebrate Paleontology 19 (Suppl. to 3): 32A.

Cope, E.D., 1868. (Remarks on Clidastes iguanavus, Nectoportheus validus and Elasmosaurus). Proceedings of the Academy of Natural Sciences Philadelphia 20: 181.

Cope, E.D., 1869. On the reptilian orders Pythonomorpha and Streptosauria. Proceedings of the Boston Society of Natural History 12: 250-266.

Dollo, L., 1882. Note sur l'ostéologie des Mosasauridæ (sic). Bulletin du Musée royal d'Histoire naturelle de Belgique 1: 55-80.

Dollo, L., 1885. Première note sur le Hainosaure, mosasaurien nouveau de la Craie brune phosphatée de Mesvin-Ciply, près Mons. Bulletin du Musée d'Histoire naturelle de Belgique 4: 25-35 (1-11).

Everhart, M., 2005. Tylosaurus kansasensis, a new species of tylosaurine (Squamata, Mosasauridae) from the Niobrara Chalk of western Kansas, USA. In: Schulp, A.S. \& Jagt, J.W.M. (eds): Proceedings of the First Mosasaur Meeting. Netherlands Journal of Geosciences 84: 231-240.

Gilmore, C.W., 1912. A new mosasauroid reptile from the Cretaceous of Alabama. Proceedings of the United States National Museum 41: 479-484.

Kuypers, M.M.M., Jagt, J.W.M., Peeters, H.H.G., de Graaf, D.Th., Dortangs, R.W., Deckers, M.J.M., Eysermans, D., Janssen, M.J. \& Arpot, L., 1998. Laat-kretaceische mosasauriers uit Luik-Limburg: nieuwe vondsten leiden tot nieuwe inzichten. Publicaties van het Natuurhistorisch Genootschap in Limburg 41: 4-47.

Lindgren, J., 2004. Stratigraphical distribution of Campanian and Maastrichtian mosasaurs in Sweden - evidence of an intercontinental marine extinction event? GFF 126: 221-229.

Lindgren, J., in press. The first record of Hainosaurus (Reptilia, Mosasauridae) from Sweden. Journal of Paleontology. 
Lindgren, J. \& Siverson, M., 2002. Tylosaurus ivoensis: a giant mosasaur from the early Campanian of Sweden. Transactions of the Royal Society of Edinburgh, Earth Sciences 93: 73-93.

Lingham-Soliar, T., 1992. The tylosaurine mosasaurs (Reptilia, Mosasauridae) from the Upper Cretaceous of Europe and Africa. Bulletin de l'Institut royal des Sciences naturelles de Belgique, Sciences de la Terre 62: 171-194.

Lingham-Soliar, T., 1993. The mosasaur Leiodon bares its teeth. In: Sarjeant, W.A.S. (ed.): Fossil vertebrates: faunas and concepts. Modern Geology 18: 443-458.

Machalski, M., Jagt, J.W.M., Dortangs, R.W., Mulder, E.W.A. \& Radwański, A., 2003. Campanian and Maastrichtian mosasaurid reptiles from central Poland. Acta Palaeontologica Polonica 48: 397-408.

Marsh, O.C., 1872. Note on Rhinosaurus. American Journal of Science (3)4(20): 147.

Massare, J.A., 1987. Tooth morphology and prey preference of Mesozoic marine reptiles. Journal of Vertebrate Paleontology 7: 121-137.

Owen, $R$., 1845. Odontography; or, a treatise on the comparative anatomy of the teeth; their morphological relations, mode of development, and microscopic structure in vertebrate animals. Hippolyte Baillère (London): 296-655.

Russell, D.A., 1967. Systematics and morphology of American mosasaurs (Reptilia, Sauria). Peabody Museum of Natural History, Yale University, Bulletin 23: 1-241.

Thurmond, J.T., 1969. New name for the mosasaur Compressidens Dollo, 1924. Journal of Paleontology 43: 1298.

Yakovlev, N.N., 1901. (Restes d'un mosasaurien trouvé dans le Crétacé supérieur du sud de la Russie). Izvestiya Geologicheska Komiteta 24: 135-152. 